\title{
Proceedings of the Annual Meeting of the Georgia Association of Mathematics Teacher Educators
}

\section{Actively Engaging Pre-service Teachers in Geometry and Measurement}

Kadian M. Callahan

Kennesaw State University, kcallah6@kennesaw.edu

DOI

10.20429/gamte.2008.020104

Follow this and additional works at: https://digitalcommons.georgiasouthern.edu/gamte-proceedings

Part of the Mathematics Commons, and the Teacher Education and Professional Development Commons

\section{Recommended Citation}

Callahan, Kadian M. (2008) "Actively Engaging Pre-service Teachers in Geometry and Measurement," Proceedings of the Annual Meeting of the Georgia Association of Mathematics Teacher Educators: Vol. 2 : Iss. 1 , Article 4.

DOI: $10.20429 /$ gamte.2008.020104

Available at: https://digitalcommons.georgiasouthern.edu/gamte-proceedings/vol2/iss1/4

This article is brought to you for free and open access by the Journals at Digital Commons@Georgia Southern. It has been accepted for inclusion in Proceedings of the Annual Meeting of the Georgia Association of Mathematics Teacher Educators by an authorized administrator of Digital Commons@Georgia Southern. For more information, please contact digitalcommons@georgiasouthern.edu. 
Actively Engaging Pre-service Teachers in Geometry and Measurement

Kadian Callahan Kennesaw

State University

kcallah6@kennesaw.edu

\begin{abstract}
Current work in mathematics education suggests that the learning experiences in which teachers engage during undergraduate study influences their knowledge of and beliefs about mathematics and the ways in which they will teach (Allen, et. al., 2008; CBMS, 2001; Hill, Rowan, \& Ball, 2005; National Research Council, 2001). However, very little is known about pre-service teachers' learning experiences and how those experiences influence their thinking about mathematics teaching and learning. The classroom excerpt described here attempts to illuminate how pre-service, elementary teachers' active engagement in the learning of geometry and measurement influences their mathematical power: a positive disposition toward mathematics, ability to reason about mathematics, facility in making connections across content strands and to other subjects, and proficiency in communicating mathematical ideas (Baroody \& Coslick, 1998; National Council of Teachers of Mathematics, 1989; Orrill \& French, 2002). The author calls for research that more closely examines students' learning experiences and educational outcomes such as mathematical power and mathematics knowledge for teaching (Hill, Rowan, \& Ball, 2005).
\end{abstract}




\section{Actively Engaging Pre-service Teachers in Geometry and Measurement}

Actively engaging students in the learning process is a central feature of many efforts to reform the teaching and learning of undergraduate mathematics (Bryant, 1998; Kvam, 2000; Millett, 2001; Roddick, 1997; Treisman, 1992). The Mathematics Association of America (MAA) developed Quantitative Reasoning for College Graduates: A Complement to the Standards (1998) to address concerns about the types of mathematical experiences that all undergraduate students should have as they develop quantitative literacy. In this report, the MAA advised that traditional lectures be replaced with more active, engaging experiences that require students to engage in teamwork, discussion, and writing about mathematics. In their recommendations for preparing $\mathrm{K}-12$ mathematics teachers, the Conference Board of the Mathematical Sciences (CMBS; 2001) also discusses the importance of actively engaging preservice teachers in the learning process. They identified active involvement as a goal of elementary and secondary mathematics education and claim that in order for teachers to actively involve students in their own classrooms they need to have similar experiences in their college mathematics courses. While there is no agreed upon definition of active learning, scholars assert that active learning involves talking, listening, writing, reading, and reflecting (Hobson, 1996; Meyers \& Jones, 1993; Yackel \& Cobb, 1996). These elements all engage the brain in different thinking processes or operations that lead to the creation of new mental structures, and thus, are elements of active learning.

In addition to engaging in active learning experiences, teachers of mathematics also need to develop mathematical power so they can foster its development in their students (Baroody \& Coslick, 1998). Scholars suggest that there is something important about having an understanding of and a positive disposition toward mathematics, being able to reason about mathematics, make connections across content strands and to subjects outside of mathematics, and being able to communicate mathematical ideas (Baroody \& Coslick, 1998; National Council of Teachers of Mathematics, 1989; Orrill \& French, 2002).

\section{Restructuring a Geometry and Measurement Course}

As I prepared to teach an undergraduate Geometry and Measurement course for preservice elementary teachers in the spring of 2008, I sought ways to create a learning environment where students would have many opportunities to learn by actively engaging in the study of mathematics and that would foster the development of their mathematical power. The course was structured with these goals in mind and incorporated the following features:

- Students sat with and regularly worked in pairs or small groups to provide them with opportunities to communicate about mathematics with each other and to share and compare ideas and problem solving strategies.

- Students were encouraged to ask questions (of the teacher or of other students) or make propositions or conjectures about mathematical ideas as they arose. Questions, propositions, and conjectures were then addressed and explored by the class.

- Students were always required to give explanations of their thinking and reasoning processes as to illuminate the process of developing mathematical ideas and solution strategies.

- Students were regularly asked to consider and identify different ways of thinking about a problem and to explore multiple strategies for solving a problem.

- Students were consistently asked entrance and exit questions that were used throughout the semester to assess students' ability to articulate their conceptual understanding of geometry and measurement in writing and their ability to make connections among different concepts. 
- Students were frequently given think-pair-shares or think-write-pair-shares so as to promote opportunities for independent thinking and formulation of ideas before sharing those ideas with other students or with the class.

- Students, as a class, periodically worked through elementary-level problems followed by watching and discussing video clips of elementary students working on those problems and developing their understanding of mathematical concepts.

\section{An Excerpt}

It was the last day of class, before the start of spring break. Some of the 21 students were getting restless and wanted to begin spring break as soon as possible. About two-thirds of the way through the class, we were finishing a word problem when I heard Jason (pseudonym, as are all proper names) whisper that he was ready to leave. I thought for a moment about his request and then reminded the class about a problem that I had written on the board at the beginning of class. It was an interesting problem that I told them I wanted to make sure we got to before the end of class. Up to that point, no one had considered the problem, but as some students were beginning to get antsy, I proposed that once a student solved that problem, he or she could leave. The problem was to find the area of the shaded region given square $\mathrm{EFGH}$ with segment $\mathrm{EF}=6 \mathrm{~cm}$ inscribed by square $\mathrm{ABCD}$ with diagonal $\mathrm{AC}=12 \mathrm{~cm}$. It should also be noted that the inner square was inscribed by the outer square using the midpoint of the sides of the outer square.

The students immediately started working on the problem, and although Jason was the first to run up to show me his solution, no one stopped working because it had already been solved. Perhaps the students were anticipating my usual questions: "Ok, so what did you do and how did you get this as your answer?" and "Can you find another way to solve it to verify that your solution is correct?" This questioning, of course, was not explicit in the deal "If you solve it, then you can leave," but the students had enough experiences in the course to anticipate this expectation and recognized that thinking about a mathematics problem in a different way can help them make sense of their solutions. Jason's First Solution:

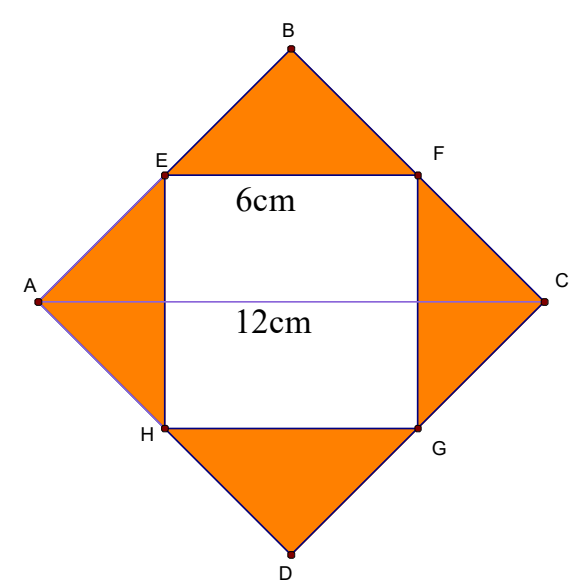

Jason: "Is this the answer?" [he showed me a sketch of the problem and solution $\left.\mathrm{A}=36 \mathrm{~cm}^{2}\right]$

Me: "Hmmm, how did you get that?"

Jason: "Well, the area of this triangle [triangle EFB] is $9 \mathrm{~cm}^{2}$ and there are 4 of them, so the total area is $36 \mathrm{~cm}^{2}$." Me: "How did you calculate the area of the triangle?"

Jason: "You know the base is $6 \mathrm{~cm}$ "cause that is given in the problem, and the height is 3 ."

Me: "How do you know that the height is 3?" Jason: "Because..., um, wait...I've got to look at that." Me: "Ok." [Jason headed back to his seat] Jason was the only male in the class. He was formerly a secondary mathematics education major and

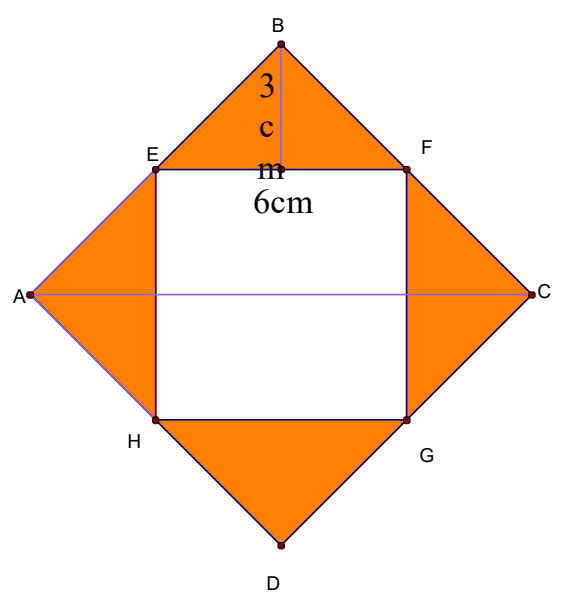
has taken more advanced math courses than most of the other elementary education majors in the 
class. He was fairly confident in his ability to do mathematics, particularly when it involved calculations. He, however, had been a bit humbled by our study of the underlying mathematical ideas involved in elementary school mathematics along with his discovery of the value in considering different ways to think about and solve problems. Jason had come to respect his classmates' perspectives and often commented, "I never would have thought of solving it that way."

As Jason walked past Laverne's table, she looked up from her work at me, "Are you going to show us how to do this?!" She was frustrated. Laverne was always frustrated. She was a non-traditional student who had very little confidence in her ability to do mathematics. She often struggled with trying to get started on a problem, mostly because she questioned herself and whether or not she was doing the problem correctly. Whenever she was asked what she has a question about, Laverne responded, "Everything!" For the unit on measurement, she had been sitting at a table with Ursula. Ursula did not say much in class unless she was asked, but she worked well with Laverne. Ursula was also very willing to begin working on something even when she was not quite sure about what to do. She was comfortable figuring things out and adjusting her solution along the way. When Laverne asked for my assistance I asked her what she had already tried; as she was gearing up to tell me that she was completely lost, Ursula tapped her to get her attention. Laverne turned her attention to Ursula and the two began discussing how to solve the problem.

A moment later, Jason came back up to explain his solution. I noticed while he was working with his group he seemed to be explaining his way of solving the problem and his group members were listening and asking questions about why his solution made sense.

Jason's Second Solution:

Jason: "Ok. I just had to go back and make sure what I did made sense."

Me: "Ok. Let's see. What did you do?"

Jason: "So if this side is 6 [refers to segment EF] and this distance is 12 [segment $\mathrm{AC}$ ], then since they are both squares, this is 3 [segment $\mathrm{AI}$ ] and this is 3 [segment $\mathrm{JC}] . "$

Me: "Ok."

Jason: "So the base of the triangle [segment HE of triangle $\mathrm{AHE}$ ] is $6 \mathrm{~cm}$ and the height (segment $\mathrm{AI}]$ is $3 \mathrm{~cm}$

so the area is 9 [pointed to his written work $1 / 2 * 6 * 3$ ]. There are 4 triangles, so the total area is $36 \mathrm{~cm}^{2}$. Is that right?"

Me: "That's interesting. So can you find another way to verify that it is correct?"

Jason: "So you want me to do it another way? Ahh!"

Me: [I smiled. He seemed to need some encouragement.]

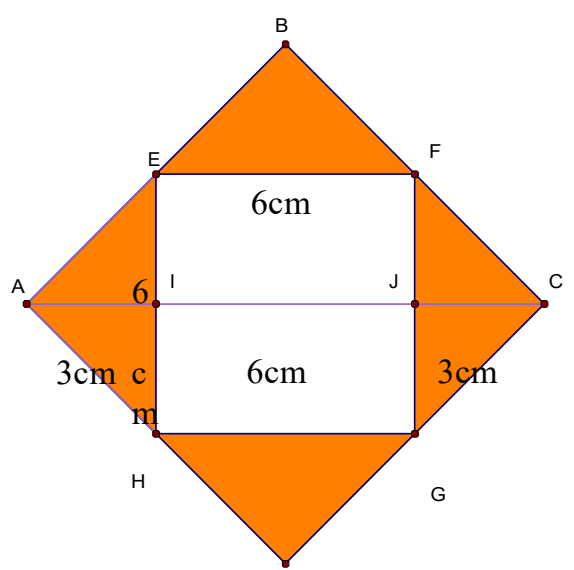

"Yes. Think about our general strategy, figure out the area and subtract the parts you don't want."

Jason: "Ok." [He headed back to his table and began discussing the problem with his group members again. This time he appeared to be listening as his group members' explained their ideas.]

Abigail, Ursula, and Laverne soon came up excitedly to show me their solutions. Abigail is a non-traditional student who does not recall ever taking geometry in high school and 
sometimes has trouble understanding what problems are asking. Throughout the class she enjoyed using different learning tools to model problems so that she could understand what she was really trying to find. She is very careful when drawing shapes and often uses graph paper to help with her precision. The graph paper helped her to see more clearly how to solve this problem.

\section{Abigail's Solution}

Abigail noted that because ABCD is a square, segment AC bisects segment BD so the distance from point $\mathrm{B}$ to the center of square $\mathrm{EFGH}[$ point $\mathrm{K}$ ] is $6 \mathrm{~cm}$. She then solved the problem by looking at congruent triangles $\mathrm{ABC}$ and $\mathrm{ADC}$, found the area of these triangles, and then subtracted out the area of square EFGH: $\mathrm{A}=2(1 / 2)(12)(6)-(6)(6)=36 \mathrm{~cm}^{2}$.

\section{Laverne and Ursula's Solution}

Ursula listened carefully to Abigail's solution, but Laverne could hardly contain her excitement. She interrupted to say that she and Ursula thought about it that way too, but ended up breaking it up into smaller triangles. As soon as Abigail finished, Laverne proudly

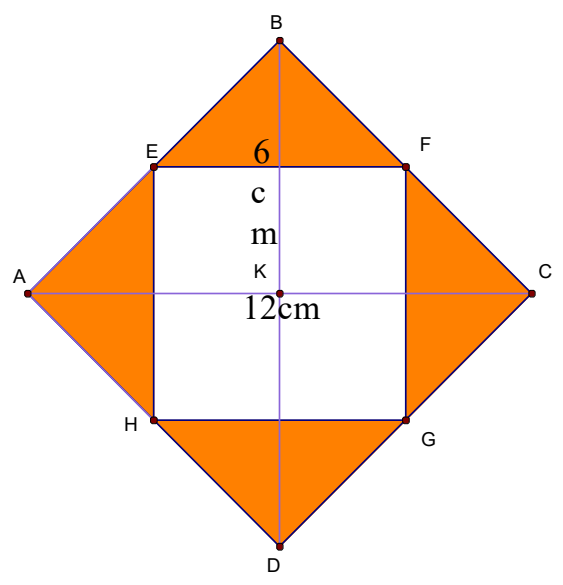
explained that they found eight congruent right triangles each with a base of $3 \mathrm{~cm}$ and a height of $3 \mathrm{~cm}$, and then calculated their areas: $A=(8)(1 / 2)(3)(3)=$ $36 \mathrm{~cm}^{2}$. When I asked Ursula and Laverne how they figured out that each of these measurements is $3 \mathrm{~cm}$, Ursula explained that if segment $\mathrm{AC}$ is $12 \mathrm{~cm}$ and segment $\mathrm{IJ}$ is $6 \mathrm{~cm}$ then you are left with $3 \mathrm{~cm}$ on either side of points I and $\mathrm{J}$ so segment $\mathrm{AI}$ is $3 \mathrm{~cm}$ and segment $\mathrm{JC}$ is $3 \mathrm{~cm}$. She told me that they know this is true because both $\mathrm{ABCD}$ and EFGH are squares and E, F, G, and $\mathrm{H}$ are midpoints. Ursula also noted that segment $\mathrm{BD}$ bisects segment $\mathrm{AC}$ and it also bisects segment $\mathrm{EF}$, so you end up with eight right triangles each with a base of $3 \mathrm{~cm}$ and a height of $3 \mathrm{~cm}$. I followed up with a couple questions directed to Laverne so I could verify that she

understood what Ursula was explaining. She appeared to understand, so I sent them off to solve the problem another way. Jason's Group's Solution Jason and his group worked out another solution and he

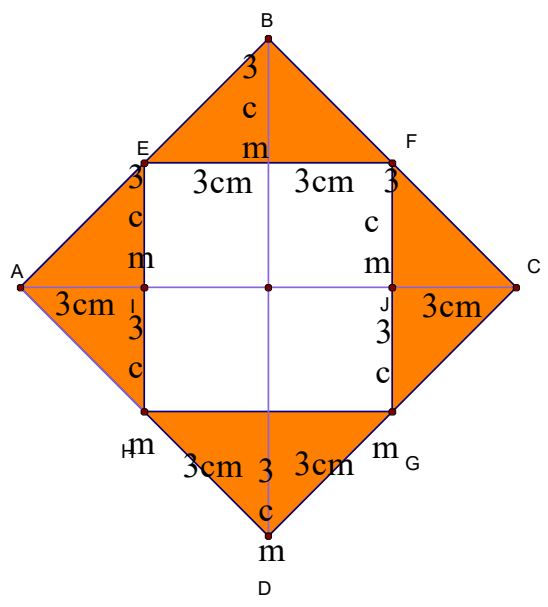

came back up to share it with me. They had sketched in segments AC and BD and noted that they bisect each other. He explained that there are four congruent quadrants, each was a right triangle with area $=(1 / 2)(6)(6)=18 \mathrm{~cm}^{2}$. So the area of square ABCD is $4(18)=72 \mathrm{~cm}^{2}$. Then you have to subtract off the small square EFGH: $A=72-(6)(6)=36 \mathrm{~cm}^{2}$. I smiled and wished Jason an enjoyable spring break - ten minutes before class was scheduled to end. Instead of rushing out the door, Jason went back to his table to discuss the problem with his group some more. I guess he wasn't in such a rush after all.

\section{Discussion}

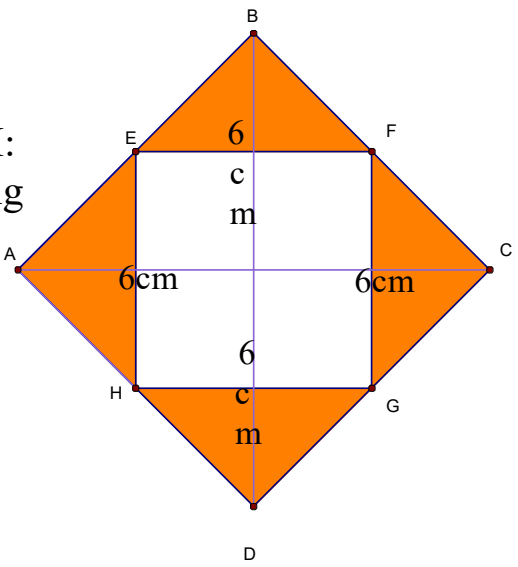


Proponents of active learning argue that new ideas are formed and discoveries are made in mathematics not by individual competition but through collaboration with colleagues, and this process is central to the nature of the subject (Mau \& Leitze, 2001; Rogers, 1992; Yackel \& Cobb, 1996). Rogers (1992) states

A pedagogy that emphasizes product deprives students of experiencing the process by which ideas in mathematics come to be and perpetuates a dualistic view of mathematics in which right answers are known by authorities and are the property of experts. Such a pedagogy strips mathematics of the context in which it was created and is based on misconceptions about its very nature. (p. 42)

Mau and Leitze (2001) add, "When we teach our mathematics students to 'be quiet and listen,' we deprive them of the opportunity to create their own meaning, disempower them, and remove their opportunity to develop autonomy" (p.38). The lack of opportunity to learn can be detrimental to students' mathematics achievement in general (National Research Council, 2001). For women in particular, robbing them of the opportunity to engage in the learning process inhibits the development of their voice in the learning of mathematics and further marginalizes them in an already male-dominated discipline (Mau \& Leitze, 2001; Rogers, 1992).

This excerpt provides some evidence of and suggests that by actively engaging students in doing mathematics, teacher educators can foster the development of mathematical power: a positive disposition toward mathematics, ability to reason about mathematics, facility in making connections across content strands and to other subjects, and proficiency in communicating mathematical ideas (Baroody \& Coslick, 1998; National Council of Teachers of Mathematics, 1989; Orrill \& French, 2002). Mathematical power could potentially influence the development of a teacher's ability to draw upon and utilize other important tools for teaching, such at mathematics knowledge for teaching (Hill, Rowan, \& Ball, 2005; Hill, Schilling, \& Ball, 2004). Presently, no studies exist that have examined pre-service teachers' mathematical power or its development during undergraduate study. Consequently, there is no information on relationships between mathematical power and other important educational outcomes. There is a need for research that provides a better understanding of the types of learning experiences that teachers should have during their teacher preparation programs.

Reports on the status of mathematics education in K-12 schools express concern about teacher preparation programs and the types of opportunities made available for pre-service teachers to learn important mathematics in meaningful ways and call for more research to understand this segment of mathematics education (CBMS, 2001; National Mathematics Advisory Panel, 2008). Teacher educators have a responsibility to address recommendations put forth by national, state, and local organizations and must continue to seek ways that create opportunities for future teachers to learn mathematics for teaching. I propose that one area that deserves further examination is the relationship between active learning opportunities and the development of mathematical power. Findings from a study that examines these components of pre-service, elementary teachers' study of mathematics is forthcoming.

\section{References}

Baroody, A. J., \& Coslick, R. T. (1998). Fostering children's mathematical power: An investigative approach to $k-8$ mathematics instruction. New Jersey: Lawrence Erlbaum Associates. 
Bryant, D.B. (1998). The small group instruction method in calculus compared with the traditional method of teaching college level calculus and effects on cognitive development, mathematical self-concept and mathematical achievement with respect to gender and race. Unpublished Dissertation. University of Maryland, College Park.

Conference Board of the Mathematical Sciences. (2001). The mathematical education of teachers: Vol. 11. Issues in mathematics education. Providence, RI: American Mathematical Society.

Hill, H. C., Rowan, B., \& Ball, D. L. (2005). Effects of teachers' mathematical knowledge for teaching on student achievement. American Educational Research Journal, 42, 371-406.

Hill, H. C., Schilling, S. G., \& Ball, D. L. (2004) Developing measures of teachers' mathematics knowledge for teaching. Elementary School Journal, 105, 11-30.

Hobson, E. H. (1996). Encouraging self-assessment: Writing as active learning. New Directions for Teaching and Learning. Using Active Learning in College Classes: A Range of Options for Faculty, 67, 45-58.

Kvam, P. H. (2000). The effect of active learning methods on student retention in engineering statistics. The American Statistician, 54(2), 136-140.

Mathematics Association of America (1998). Quantitative reasoning for college graduates: A complement to the standards. Retrieved June 23, 2004, from http://www.maa.org/past/ql/ql toc.html\#summary

Mau S. T., \& Leitze, A. R. (2001). Powerless gender or genderless power? The promise of constructivism for females in the mathematics classroom. In W. Secada, J. Jacobs, J. Becker, \& G. Gilmer (Eds.), Changing the Faces of Mathematics: Perspectives on Gender (pp. 37-41). Reston, VA: National Council of Teachers of Mathematics.

Meyers, C., \& Jones, T. B. (1993). Promoting Active Learning: Strategies or the College Classroom. San Francisco, CA: Jossey-Bass..

Millett, K.C. (2001). Making large lectures effective: An effort to increase student success. In D. Holton (Ed.), The Teaching and Learning of Mathematics at University Level: An ICIM Study. (pp. 137-152). Netherlands: Klumer Academic Publishers.

National Council of Teachers of Mathematics. (1989). Curriculum and evaluation standards for school mathematics. Reston, VA: National Council of Teachers of Mathematics.

National Mathematics Advisory Panel. (2008). Foundations for success: Final report. Washington, DC: Author.

National Research Council. (2001). Adding it up: Helping children learn mathematics. In J. Kilpatrick, J. Swafford, \& B. Findell (Eds.), Mathematics learning study committee, center for education, division of behavioral and social sciences, and education. Washington, DC: National Academies Press.Orrill, R., \& French, V. (2002). Mathematics framework for the 2003 National Assessment of Educational Progress. Washington, DC: National Assessment Governing Board. Retrieved August 25, 2008, from http://www.nagb.org/pubs/math_fw_03.pdf

Roddick, C. D. (1997). A comparison study of students from two calculus sequences on their achievement in calculus-dependent courses. Unpublished Dissertation. The Ohio State University.

Rogers, P. (1992). Thoughts on power and pedagogy. In L. Burton (Ed.) Gender and Mathematics: An International Perspective. London: Cassell. 
Treisman, U. (1992). Studying students studying calculus: A look at that lives of minority mathematics students in college. [Electronic version]. The College Mathematics Journal, 23(5), 362-372.

Yackel, E., \& Cobb, P. (1996). Sociomathematical norms, argumentation, and autonomy in mathematics. Journal for Research in Mathematics Education, 27(4), 458-477. 